\title{
Pelayanan Kesehatan Ibu dan Kematian Neonatal
}

\author{
Maternal Health Care and Neonatal Mortality
}

Desy Fitri Yani* Artha Budi Susila Duarsa**

\author{
*Dinas Kesehatan Kabupaten Lampung Timur, **Fakultas Kedokteran Universitas YARSI
}

\begin{abstract}
Abstrak
Indonesia bersama seluruh negara berkembang berupaya mencapai kesepakatan Millenium Development Goals (MDGs) dengan salah satu sasaran menurunkan angka kematian neonatal dari 20 per 1.000 kelahiran hidup menjadi 15 per 1.000 kelahiran hidup. Penelitian ini bertujuan mengetahui hubungan pelayanan kesehatan ibu dengan kematian neonatal di Kabupaten Lampung Timur tahun 2011. Penelitian dengan desain studi kasus kontrol ini mengamati kasus ibu yang mengalami kematian neonatal dan kontrol ibu yang tidak mengalami kematian neonatal. Analisis multivariat menemukan pelayanan antenatal dan pertolongan persalinan berhubungan secara signifikan dengan kematian neonatal, setelah mengendalikan variabel umur ibu dan riwayat kehamilan $(O R=16,32$; nilai $p$ $=0,000)$; dan $(O R=18,36$; nilai $p=0,31)$. Bayi yang dilahirkan dari lbu dengan pelayanan antenatal tidak lengkap berisiko mengalami kematian neonatal 16,32 dan 18,36 kali lebih besar daripada bayi yang dilahirkan. Ibu dengan pelayanan antenatal lengkap dan penolong persalinan profesional. Tidak ada hubungan penolong persalinan dengan kematian neonatal, setelah mengontrol variabel pelayanan antenatal, umur ibu, riwayat kehamilan, riwayat penyakit, dan riwayat persalinan. Disarankan meningkatkan kualitas pelayanan antenatal dengan memerhatikan faktor umur ibu dan riwayat persalinan, mengembangkan kegiatan audit maternal perinatal serta meningkatkan keterampilan petugas penolong persalinan.

Kata kunci: Ibu hamil, kematian neonatal, pelayanan kesehatan
\end{abstract}

\footnotetext{
Abstract

All developing countries including Indonesia seek to reach agreement the Millennium Development Goals (MDG's). It is objectives include reducing neonatal mortality by 25 percent from 20 per 1,000 live birth to 15 per 1,000 live births. This study aimed to determine the relationship of maternal health services with neonatal mortality in East Lampung District in 2011. This study used case control design to compare between the groups of mother whom have neonatal deaths (cases) and neonatal life (control) in East Lampung
}

District in 2011. The result on antenatal care variables found that antenatal care and birth attendant had significant correlation with neonatal death, after controlling age and pregnancy history variable ( $p$ value $=0.000, \mathrm{OR}=$ 16.32; $p$ value $=0.31, O R=18.36$ ). The babies from mothers who did not get completed prenatal care risk of 16.32 times have neonatal death than babies born from mothers who received completed maternal care. There was no association between neonatal mortality and birth attendant, after controling variables of antenatal care, maternal age, pregnancy history, medical history and chilbirth history. Based on this study, it is suggested to increase activity of maternal perinatal audit, improve the quality of antenatal care, maternal delivery, and develop other support activities to prevent neonatal mortality in East Lampung District.

Keywords: Pregnant mothers, neonatal mortality, health care

\section{Pendahuluan}

Indonesia bersama semua negara berkembang berupaya mencapai kesepakatan Millenium Development Goals (MDGs) dengan salah satu sasaran adalah menurunkan angka kematian neonatal sekitar 25\% dari 20 per 1.000 kelahiran hidup menjadi 15 per 1.000 kelahiran hidup. Target keempat MDGs adalah menurunkan angka kematian balita (AKBA) hingga dua per tiga dalam kurun waktu 1990 - 2015. Indikator yang digunakan antara lain angka kematian balita, angka kematian bayi (AKB), angka kematian neonatal masing-masing per 1.000 kelahiran hidup. Di Indonesia, pada tahun 2007, angka kematian balita 44 per 1.000 kelahiran hidup, angka kematian bayi 34 per 1.000 kelahiran hidup, angka

Alamat Korespondensi: Desy Fitri Yani, Dinas Kesehatan Lampung Timur, Jl. Buay Subing, Komplek Perkantoran Pemda, Sukadana Lampung Timur 34194, Hp.081279061616,e-mail: desyf8@gmail.com 
kematian neonatal 19 per 1.000 kelahiran hidup, ditargetkan pada tahun 2015 turun menjadi 15 per 1.000 kelahiran hidup, 32 per 1.000 kelahiran hidup, 23 per 1.000 kelahiran hidup. ${ }^{1}$

Dinas Kesehatan Lampung Timur melaporkan pada tahun 2011, dari 21.454 bayi lahir hidup terdapat 120 kasus kematian bayi dan 114 kasus di antaranya adalah kematian neonatal $(95 \%)$. Penyebab kematian neonatal adalah berat badan lahir rendah (55\%), asfiksia (22\%), tetanus neonatorum $(0,8 \%)$, dan penyebab lain-lain $(16 \%)$. Pemanfaatan pelayanan kesehatan ibu hamil terlihat pada cakupan kunjungan kesehatan ibu dan anak di Kabupaten Lampung Timur tahun 2011 meliputi kunjungan ibu hamil K1 sekitar 91,3\% dari target program $100 \%$, cakupan K4 ibu hamil $88 \%$ dengan target $90 \%$, dan cakupan persalinan tenaga kesehatan sekitar $90,9 \%$ dari target program $85 \% .^{2}$

Pelayanan kesehatan ibu hamil bertujuan mengawasi dan menangani ibu hamil dan ibu bersalin, asuhan dan pemeriksaan ibu sesudah persalinan, asuhan neonatus, pemeliharaan dan pemberian laktasi. ${ }^{3}$ Penelitian sebelumnya menyatakan hubungan yang bermakna antara pelayanan antenatal dengan kematian neonatal, tetapi ada juga penelitian yang menemukan penolong persalinan tidak berhubungan dengan kematian neonatal. Dengan cakupan pelayanan kesehatan ibu hamil yang baik, tetapi kasus kematian neonatal masih menjadi masalah. Penelitian ini bertujuan mengetahui hubungan pelayanan kesehatan ibu hamil dengan kematian neonatal di Kabupaten Lampung Timur tahun 2011.

\section{Metode}

Desain penelitian yang digunakan adalah kasus kontrol. Kelompok kasus adalah ibu dengan kematian neonatal dan kontrol adalah kelompok ibu yang tidak mengalami kematian neonatal. Variabel counfounding meliputi umur ibu, paritas, jarak antarkelahiran, riwayat penyakit, riwayat kehamilan, dan riwayat persalinan. Populasi penelitian adalah seluruh ibu yang melahirkan bayi lahir hidup di Kabupaten Lampung Timur periode Januari sampai Desember 2011 yang berjumlah 21.454 orang.

Sampel kasus adalah ibu yang bayinya lahir hidup dan mengalami kematian neonatal pada periode Januari sampai Desember 2011. Kontrol adalah ibu dengan bayi lahir hidup dan tidak mengalami kematian pada periode neonatal dari bulan Januari sampai dengan Desember 2011. Pemilihan kontrol disesuaikan dengan bulan kejadian kasus dengan waktu kelahiran yang paling berdekatan. Kontrol berada dalam satu wilayah puskesmas yang sama dengan kejadian kasus. Perbandingan kasus dan kontrol adalah $1: 1$. Sampel pada penelitian ini adalah seluruh kasus kematian neonatal di Kabupaten Lampung Timur tahun 2011 yang berjumlah 114 ibu dan kontrol 114 ibu dengan jumlah keseluruhan $228 \mathrm{ibu}$.
Variabel dependen adalah kematian neonatal dan variabel independen adalah pelayanan antenatal dan penolong persalinan. Variabel yang dipilih sebagai variabel confounding adalah umur ibu, paritas, jarak antarkelahiran, riwayat penyakit ibu, riwayat persalinan dan riwayat kehamilan ibu. Pada variabel pelayanan antenatal yang menjadi faktor pengganggu adalah, umur ibu, paritas, jarak kelahiran, riwayat penyakit, riwayat persalinan, dan riwayat kehamilan. Pada variabel penolong persalinan yang menjadi faktor pengganggu adalah umur ibu, paritas, jarak kelahiran, riwayat penyakit, riwayat persalinan, dan riwayat kehamilan. Data primer dikumpulkan dengan teknik wawancara menggunakan acuan kuesioner, yang dilaksanakan oleh bidan koordinator Unit kesehatan ibu dan anak puskesmas pada bulan Mei tahun 2012. Data sekunder diambil dari laporan audit kematian maternal perinatal Dinas Kabupaten Lampung Timur tahun 2011 dan buku kesehatan ibu dan anak responden. Analisis bivariat dilakukan dengan kai kuadrat dan analisis multivariat menggunakan regresi logistik, model estimasi, dan hubungan variabel pelayanan antenatal dengan kematian neonatal dapat terlihat setelah mengendalikan variabel pengganggu.

\section{Hasil}

Penelitian ini menemukan sekitar 34\% responden mendapat pelayanan antenatal yang tidak lengkap, dan $11 \%$ dengan penolong persalinan bukan tenaga kesehatan. Responden mempunyai satu anak dan lebih dari empat anak sekitar $60 \%$. Responden yang mempunyai riwayat penyakit dan masuk dalam kelompok risiko sekitar $7 \%$. Responden yang mempunyai riwayat persalinan dengan komplikasi sekitar 4\% dan yang mempunyai riwayat kehamilan berisiko sekitar $19 \%$.

Distribusi hasil bivariat kelompok kasus dan kontrol memperlihatkan beberapa variabel terdistribusi secara berbeda sehingga berpotensi berhubungan dengan kematian neonatal. Variabel tersebut antara lain meliputi pelayan-an antenatal, pertolongan persalinan, umur ibu, riwayat penyakit dan riwayat persalinan, sedangkan paritas dan jarak kelahiran tidak ditemukan hubungan dengan kematian neonatal (Tabel 1).

Tabel 1. Distribusi Variabel Independen pada Kelompok Kasus dan Kontrol

\begin{tabular}{lcccc}
\hline Variabel & Kasus (\%) & Kontrol (\%) & Nilai p & OR \\
\hline Pelayanan antenatal & 55,3 & 12,3 & 0,00 & 8,82 \\
Pertolongan persalinan & 16,7 & 5,3 & 0,00 & 3,60 \\
Umur ibu & 39,5 & 9,6 & 0,00 & 6,10 \\
Paritas & 63,2 & 57,0 & 0,34 & 1,29 \\
Jarak kelahiran & 78,9 & 80,7 & 0,74 & 0,89 \\
Riwayat penyakit & 11,4 & 2,6 & 0,01 & 4,76 \\
Riwayat persalinan & 6,1 & 0,9 & 0,03 & 7,39 \\
Riwayat kehamilan & 29,8 & 8,8 & 0,00 & 4,42 \\
\hline
\end{tabular}


Tabel 2. Hubungan Pelayanan Antenatal dengan Kematian Neonatal

\begin{tabular}{llll}
\hline Variabel Independen & Nilai p & OR & IK 95\% \\
\hline Pelayanan antenatal & 0,00 & 16,32 & $7,30-36,45$ \\
Umur ibu & 0,00 & 11,28 & $4,69-27,11$ \\
Riwayat kehamilan & 0,00 & 8,02 & $3,16-20,36$ \\
\hline
\end{tabular}

Tabel 3. Hubungan Pertolongan Persalinan dengan Kematian Neonatal

\begin{tabular}{llll}
\hline Variabel Independen & Nilai p & OR & IK 95\% \\
\hline Pertolongan persalinan & 0,31 & 18,36 & $0,56-5,92$ \\
Pelayanan antenatal & 0,00 & 14,75 & $6,57-33,10$ \\
Umur ibu & 0,00 & 11,42 & $4,69-27,80$ \\
Riwayat kehamilan & 0,00 & 6,02 & $2,26-16,03$ \\
Riwayat penyakit & 0,08 & 3,83 & $0,85-17,28$ \\
Riwayat persalinan & 0,05 & 11,14 & $0,97-127,74$ \\
\hline
\end{tabular}

Berdasarkan hasil bivariat, variabel yang memenuhi kriteria kandidat model multivariat (nilai $\mathrm{p} \leq 0,25$ ) adalah pelayanan antenatal, pertolongan persalinan, umur ibu, riwayat penyakit, riwayat persalinan dan riwayat kehamilan. Setelah melakukan tahapan pemodelan identifikasi variabel adalah kovariat multivariat, pemodelan lengkap, eliminasi interaksi, penetapan model baku (gold standard), dan penetuan model akhir.

Model hubungan pelayanan antenatal dengan kematian neonatal di Kabupaten Lampung Timur tahun 2011 memperlihatkan hubungan yang signifikan antara pelayanan antenatal dengan kematian neonatal setelah mengontrol variabel umur ibu dan riwayat kehamilan. Bayi yang dilahirkan dari ibu yang mendapatkan pelayanan antenatal tidak lengkap berisiko 16,32 kali lebih besar untuk mengalami kematian neonatal daripada bayi dari ibu dengan pelayanan antenatal lengkap, dengan interval 7,30 sampai 36,45 kali (Tabel 2).

Berdasarkan model akhir hubungan pertolongan persalinan dengan kematian neonatal diketahui tidak ada hubungan pertolongan persalinan dengan kematian neonatal di Kabupaten Lampung Timur Tahun 2011 setelah mengontrol variabel pelayanan antenatal, umur $\mathrm{ibu}$, riwayat kehamilan, riwayat penyakit dan riwayat persalinan (Tabel 3).

\section{Pembahasan}

Kelemahan pada rancangan kasus kontrol adalah recall bias karena kemampuan responden mengingat kejadian yang telah berlalu sangat terbatas. Upaya yang dilakukan adalah mencari responden yang telah melahirkan dalam waktu satu tahun terakhir dan membuat pertanyaan yang mudah dimengerti responden.

Mayoritas responden kelompok kasus mendapatkan pelayanan antenatal yang tidak lengkap, sebaliknya mayoritas kelompok kontrol mendapat pelayanan antenatal lengkap. Penelitian sebelumnya, bayi dari ibu yang pe- meriksaan antenatal yang tidak lengkap mempunyai odds ratio $(\mathrm{OR})$ untuk mati pada periode natal sekitar 2,70 kali $95 \%$ confidence intervals $(\mathrm{CI})=1,53-4,78$ dan nilai $\mathrm{p}<0,001$, dibandingkan dengan bayi dari ibu yang melakukan pemeriksaan antenatal dengan baik. ${ }^{4}$ Ada pengaruh pelayanan pelayanan antenatal pada ibu dengan kematian neonatal. 5

Analisis multivariat model akhir hubungan pelayanan antenatal dengan kematian neonatal di Kabupaten Lampung Timur tahun 2011 menemukan hubungan antara pelayanan antenatal dengan kematian neonatal, setelah mengontrol variabel umur ibu dan riwayat kehamilan. Variabel umur ibu dan riwayat kehamilan merupakan confounding pada variabel utama pelayanan antenatal. Selain pelayanan antenatal yang merupakan variabel utama, umur ibu, dan riwayat kehamilan juga mempengaruhi kejadian kematian neonatal. Nilai $\mathrm{OR}=16,32$ menunjukkan bahwa bayi yang dilahirkan dari Ibu yang mendapatkan pelayanan antenatal tidak lengkap berisiko 16,32 kali mengalami kematian neonatal dibandingkan dengan bayi dari Ibu yang mendapatkan pelayanan antenatal lengkap dengan 95\% CI OR = 7,30-36,45 kali.

Tidak ada perubahan signifikan nilai $\mathrm{p}$ pada hasil analisis bivariat dibandingkan dengan hasil uji multivariat, tetapi terjadi perubahan pada nilai OR dari 8,82 menjadi 16,32 . Semakin banyak ibu yang mendapatkan pelayanan antenatal yang tidak lengkap, semakin besar risiko terjadinya kematian neonatal. Pelayanan antenatal berhubungan lebih erat dengan kematian neonatal setelah mengontrol variabel lain umur ibu dan riwayat kehamilan dan lebih meningkat risiko kematian neonatal. Pelayanan antenatal yang tidak lengkap pada ibu berhubungan sangat erat dengan kematian neonatal, tidak membedakan ibu dari kelompok umur berisiko atau tidak dan mempunyai riwayat kehamilan berisiko atau tidak, mempunyai riwayat kehamilan yang bermasalah atau tidak.

Penelitian sebelumnya, menemukan hubungan bermakna antara kunjungan pelayanan antenatal dengan kematian perinatal (nilai $\mathrm{p}=0,0000$ ), nilai $\mathrm{OR}=9,9$. Ibu dengan kunjungan pelayanan antenatal yang tidak lengkap (K1 dan $\mathrm{K} 4<4$ ) berisiko 9,9 kali lebih besar mengalami kematian perinatal dibandingkan dengan ibu yang melakukan kunjungan pelayanan antenatal lengkap. ${ }^{5}$ Bayi yang dilahirkan dari ibu yang pelayanan antenatal tidak adekuat berisiko mengalami kematian perinatal 2,6 kali dibandingkan dengan bayi yang dilahirkan dari ibu dengan pelayanan antenatal yang adekuat. Semakin baik pelayanan antenatal semakin tinggi perlindungan yang diberikan terhadap ancaman kematian janin. 6

Tujuan pemeriksaan ibu hamil adalah menyiapkan fisik dan mental ibu dan anak dalam kehamilan seoptimal mungkin, persalinan dan nifas sehingga didapat- 
kan anak dan ibu yang sehat. Pemeriksaan kehamilan juga mempunyai tujuan khusus mengenali dan menangani penyulit yang dijumpai pada kehamilan, persalinan, dan nifas, mengenali dan mengobati penyakit, menurunkan angka morbiditas dan mortalitas ibu dan anak. ${ }^{7}$ Perbaikan angka kematian neonatal dapat dicapai dengan pemberian pengawasan antenatal untuk semua wanita hamil dan dengan menemukan serta memperbaiki berbagai faktor yang memengaruhi keselamatan janin dan neonatus. ${ }^{8}$

Ada hubungan yang signifikan antara pertolongan persalinan dengan kematian neonatal. Bayi yang dilahirkan ibu yang mendapat pertolongan persalinan bukan dengan tenaga kesehatan berisiko 3,6 kali untuk mengalami kematian neonatal dibandingkan dengan bayi yang mendapatkan pertolongan persalinan dari tenaga kesehatan. Penelitian sebelumnya menemukan hubungan yang bermakna antara penolong persalinan dengan kematian neonatal. Ada hubungan bermakna antara penolong persalinan dengan kematian neonatal. Bayi yang dilahirkan dari ibu yang ditolong oleh dukun berisiko kematian neonatal 6,07 kali lebih besar dibanding bayi yang lahir ditolong oleh tenaga kesehatan. ${ }^{9}$ Ibu yang persalinannya ditolong oleh nontenaga kesehatan, berisiko mengalami eklampsi 3,7 kali, dan berisiko mengalami partus lama 2,77 kali sehingga meningkatkan risiko kematian pada periode neonatal. ${ }^{10}$

Hasil analisis multivariat model akhir hubungan pertolongan persalinan dengan kematian neonatal, setelah mengendalikan variabel pelayanan antenatal, umur ibu, riwayat kehamilan, riwayat penyakit dan riwayat persalinan, tidak menemukan hubungan yang bermakna antara pertolongan persalinan dengan kematian neonatal di Kabupaten Lampung Timur tahun 2011. Hasil ini berbeda dengan hasil bivariat yang menyatakan hubungan yang signifikan antara pertolongan persalinan dengan kematian neonatal. Setelah dilakukan uji multivariat, dengan mengontrol variabel yang berpengaruh lainnya, hasilnya menjadi tidak berhubungan. Sesuai dengan penelitian sebelumnya, tidak ada hubungan antara pertolongan persalinan dengan kematian perinatal. ${ }^{11}$ Variabel penolong persalinan pada uji bivariat berhubungan dengan kematian neonatal, tetapi setelah dipengaruhi faktor lain pada uji multivariat terjadi perubahan nilai $\mathrm{p}$, faktor pelayanan antenatal, umur ibu, riwayat kehamilan, riwayat penyakit dan riwayat persalinan juga berpengaruh terhadap kematian neonatal. Untuk mengurangi risiko kematian neonatal dini diperlukan penanganan sejak masa hamil berupa pelayanan antenatal. ${ }^{12}$

Kematian neonatal tidak hanya disebabkan oleh pertolongan persalinan sesuai dengan teori tetapi lebih disebabkan oleh kunjungan pelayanan antenatal yang dilakukan ibu selama kehamilan. Selain itu, faktor lain yang berpengaruh adalah umur ibu, riwayat kehamilan, riwayat penyakit dan riwayat persalinan. Berdasarkan tren kematian neonatal tahun 1995 - 2007, penyebab kematian neonatal adalah gangguan pernapasan ketika lahir, prematur dan berat badan lahir rendah yang dipengaruhi oleh faktor riwayat kehamilan ibu, riwayat penyakit dan riwayat komplikasi persalinan. ${ }^{13}$ Kematian neonatal di fasilitas pelayanan kesehatan, menjadi bahan pertimbangan untuk mencari pemecahan masalah agar dapat dikurangi.

\section{Kesimpulan}

Penelitian ini menemukan hubungan antara pelayanan antenatal dengan kematian neonatal di Kabupaten Lampung Timur tahun 2011, setelah mengontrol variabel umur ibu dan riwayat kehamilan. Bayi yang dilahirkan dari ibu yang mendapatkan pelayanan antenatal tidak lengkap berisiko 16,32 kali mengalami kematian neonatal dibanding dengan bayi yang dilahirkan dari Ibu yang mendapatkan pelayanan antenatal lengkap, dengan interval antara 7,30 sampai 36,45 kali. Tidak ada hubungan pertolongan persalinan dengan kematian neonatal di Kabupaten Lampung Timur tahun 2011 setelah mengontrol variabel pelayanan antenatal, umur ibu, riwayat kehamilan, riwayat penyakit dan riwayat persalinan.

\section{Saran}

Pelayanan antenatal perlu mendapat prioritas utama dalam peningkatan kualitas bersama faktor umur ibu dan riwayat persalinan. Tindakan yang dapat dilakukan antara lain penjaringan ibu hamil dengan faktor risiko umur dan riwayat persalinan, memantau ibu hamil menggunakan buku kohort ibu, memberdayakan ibu, memanfaatkan buku KIA sebagai alat dokumentasi pencatat riwayat kesehatan dan sebagai bahan pelajaran karena berisi pengetahuan kehamilan yang penting sehingga dapat mengurangi risiko kematian neonatal dan memberikan penyuluhan tentang usia reproduksi sehat. Dinas kesehatan Kabupaten Lampung Timur perlu mengembangkan kegiatan audit maternal perinatal di sebagai sarana pembelajaran para bidan pelaksana pelayanan untuk mengetahui faktor risiko kematian neonatal. Meningkatkan keterampilan penolong persalinan (APN) dan penanganan kegawat daruratan obstetri neonatal (PDGON) mengingat kematian neonatal masih terjadi di fasilitas kesehatan. Meningkatkan pelayanan kualitas dan kuantitas antenatal dengan lebih banyak memberikan informasi kepada ibu hamil tentang pelayanan antenatal melalui penyuluhan di posyandu atau kelas ibu hamil dan melakukan kunjungan rumah ibu hamil yang hilang dari kunjungan. 


\section{Daftar Pustaka}

1. Badan Perencanaan dan Pembangunan Nasional. Laporan perkembangan pencapaian Millenium Development Goals Indonesia. Jakarta: Badan Perencanaan dan Pembangunan Nasional; 2010.

2. Dinas Kesehatan Lampung Timur. Evaluasi program kesehatan keluarga. Lampung: Dinas Kesehatan Lampung; 2007.

3. Manuaba IG. Ilmu kebidanan, penyakit kandungan dan keluarga berencana untuk pendidikan bidan. Jakarta: Penerbit Buku Kedokteran; 2010.

4. Ronoatmojo S. Faktor risiko kematian neonatal di Kecamatan keruak, NTB 1992 - 1993 [disertasi]. Yogyakarta: Universitas Gadjah Mada; 1996.

5. Sriwahyuni. Hubungan faktor ibu dan pelayanan kesehatan dengan kematian neonatal di Kabupaten Pidie tahun 2008 [tesis]. Medan: Universitas sumatra Utara; 2009.

6. Ning S. Kematian perinatal hubungannya dengan praktek kesehatan ibu selama kehamilan di Kota Bekasi. Jakarta: Pusat Penelitian Ekologi Kesehatan, Badan Penelitian dan Pengembangan Kesehatan; 2001.
7. Mochtar R. Sinopsis obstetri fisiologi obstetri patologi. Jakarta: Penerbit Buku Kedokteran; 1998.

8. Wiknjosatro H. Ilmu kebidanan. Jakarta: Yayasan Bina Pustaka Sarwono Prawirohardjo; 2002.

9. Prabamurti NP. Analisis faktor risiko status kematian neonatal (studi kasus kontrol di Kecamatan Losari kabupaten Brebes tahun 2006). Jurnal Promosi Kesehatan Indonesia. 2008; 3 (1): 1-9.

10. Astuti DW. Hubungan penyebab kematian neonatal menurut umur ibu saat melahirkan, penolong persalinan dan GPOA di Indonesia. Surabaya: Pusat Penelitian dan Pengembangan Kesehatan Sistem dan Kebijakan; 2009.

11. Mahmudah U, Hary CW, Wahyuningsih A. Analisis faktor ibu dan bayi yang berhubungan dengan kejadian kematian perinatal. Kesmas Jurnal Kesehatan Masyarakat. 2011; 7 (1); 46-56 [diakses tanggal 5 November 2012]. Diunduh dalam: http://journal.unnes.ac.id/nju/index.php/kemas/article/view/1792/1983. 